ROSANA RAMOS DUARTE

\title{
UM OLHAR SENSÍVEL À CRIANÇA
}

\section{DEPARTAMENTO DE EDUCAÇÃO}

Coordenação Central de Extensão

Curso de Especialização em Educação Infantil:

Perspectivas de Trabalho em Creches e Pré-Escolas

Orientadora: Silvia Néli Falcão Barbosa 


\section{Pontifícia Universidade Católica \\ do Rio de Janeiro}

ROSANA RAMOS DUARTE

\section{UM OLHAR SENSÍVEL À CRIANÇA}

Monografia apresentada ao Programa de PósGraduação em Educação da PUC-RIO como requisito parcial para obtenção do título de Especialista em Educação Infantil.

Orientadora: Silvia Néli Falcão Barbosa

Coordenação Central de Extensão

Curso de Especialização em Educação Infantil: Perspectivas de Trabalho em Creches e Pré-Escolas

Rio de Janeiro,

Outubro de 2016

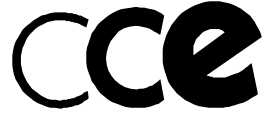

COORDENAÇÃo

CEnTRAL DE

EXTENSÃo 


\section{Resumo}

Esta monografia é parte de uma pequena reflexão do meu olhar como educadora para a educação infantil em instituições privadas da zona sul do Rio de janeiro. Sendo assim, no capítulo I, traço um olhar às leis e documentos analisando-os e relacionando-os ao cotidiano escolar infantil. Depois, mostro e discuto como a criança pode ser vista e tratada nas creches dialogando com Maria Malta Campos (2009) em seu texto Critérios para um atendimento em creches que respeite os direitos fundamentais das crianças. No capítulo II procuro mostrar, de maneira simples e resumida o lugar do olhar exotópico, que significa desdobramento de olhares a partir de um lugar exterior. Esse lugar exterior permite, segundo Bakhtin, que se veja do sujeito algo que o próprio sujeito nunca pode ver. Essa atitude comporta um olhar comprometido e ético e sensível, ilustrado pela fotografia. No capítulo III olho para a criança através da observação direta de pequenos eventos no cotidiano de uma creche privada no bairro Jardim Botânico dialogando com a autora Maria Malta Campos (2009) em seu texto Critérios para um atendimento em creches que respeite os direitos fundamentais das crianças. Acima de tudo, este breve estudo pretende mostrar que olhar é possível, o olhar além do olhar, o olhar carregado de sensibilidade, escuta e doação.

Palavras chave: Olhar sensível - Criança - Brincar - Direitos 


\section{Agradecimentos}

Agradeço aos professores que desempenharam com dedicação as aulas ministradas proporcionando conhecimento, provocando em mim um olhar além, um olhar mais sensível ao universo infantil.

Meu agradecimento especial à professora Silvia Néli Falcão Barbosa que teve um olhar acolhedor às minhas dificuldades incentivando-me a tentar vencer o medo até o último momento, sendo fundamentalmente preciosa na elaboração e conclusão deste trabalho.

A todos que direta ou indiretamente fizeram parte da minha formação o meu muito obrigada. 


\section{Sumário}

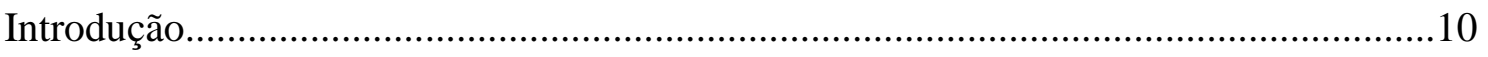

Capítulo I - Um olhar para a legislação.................................................................. 11

1.1 - Nossas crianças têm direito à brincadeira........................................................ 14

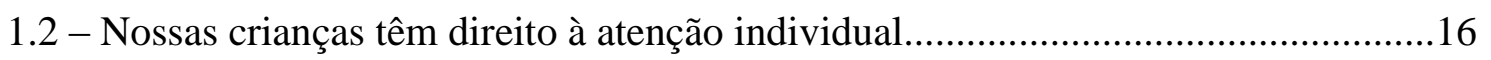

1.3 - Nossas crianças têm direito a um ambiente aconchegante, seguro e

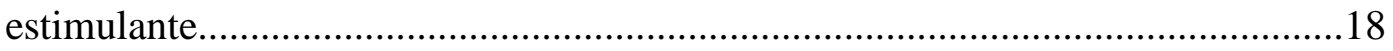

1.4 - Nossas crianças têm direito ao contato com a natureza........................................20

1.5 - Nossas crianças têm direito a desenvolver sua identidade cultural, racial e

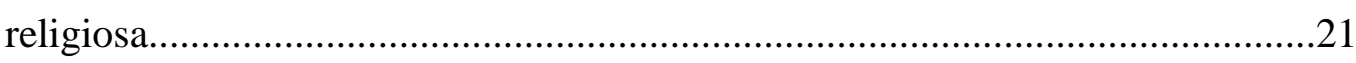

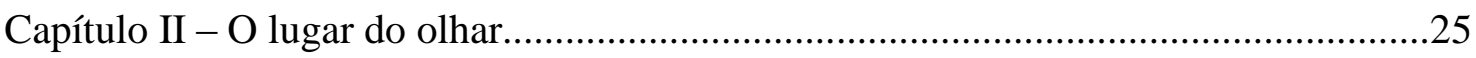

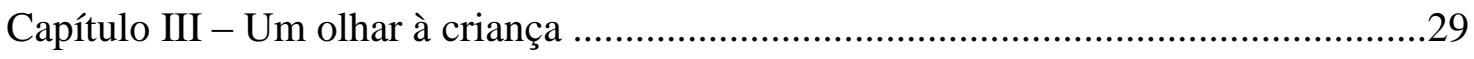

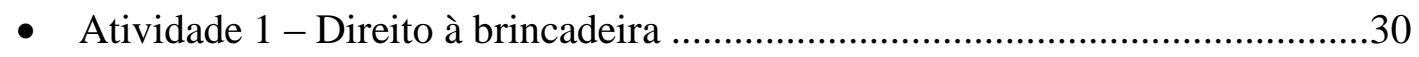

- Atividade 2 - Direito ao movimento em espaços amplos e ao ar livre.................31

- Atividade 3 - Direito à atenção individual..........................................................34

- Atividades 4 e 5 - Nossas crianças têm direito a um ambiente aconchegante,

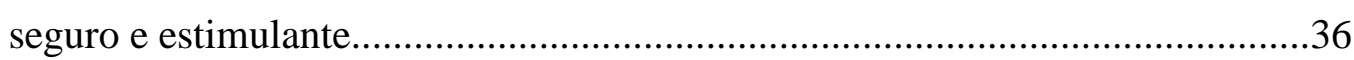

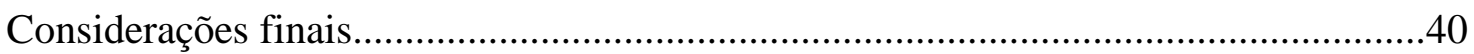

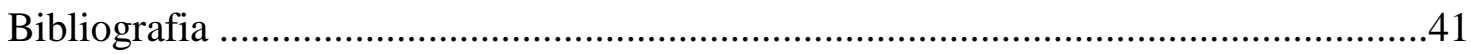




\section{Introdução}

Esta monografia provocou em mim alguns sentimentos que sondam a minha alma há alguns anos. Tenho uma dificuldade exacerbada em escrever, tenho medo e acredito piamente que sou incapaz. Foi muito difícil conseguir produzir.

Entrei no curso de Especialização em Educação Infantil da PUC-Rio buscando capacitação teórica de qualidade, encontrei além. Encontrei a possibilidade de ressignificar o meu olhar que com o tempo ficou cristalizado. Ressignificar o olhar trouxe-me até esse momento da escrita e me fez pensar sobre falar desse olhar.

Para compor esse olhar eu trouxe dois trabalhos da minha trajetória no curso, um sobre a observação direta de propostas no cotidiano de uma turma de maternal $1 \mathrm{em}$ uma creche privada da zona sul do Rio de Janeiro e outro sobre um olhar sensível através da fotografia. Esse último foi elaborado a partir de reflexões sobre as fotografias que tirei da organização e realização da exposição feita pela turma como culminância da nossa trajetória nas disciplinas Cotidiano de Trabalho em Creches e Pré - Escolas e A Criança e a Cultura.

Sendo assim, no capítulo I, traço um olhar sobre a legislação, normas nacionais que nos ajudam a entender a educação como direito de todos, bem como orientam as instituições de educação infantil a valorizar a autonomia da criança, a solidariedade e do respeito às diferenças.

No capítulo II procuro mostrar, de maneira simples e resumida o lugar do olhar exotópico e sensível, ilustrado pela fotografia, instrumento usado diariamente por mim no cotidiano escolar e na minha vida.

No capítulo III olho para a criança através da observação direta de pequenos eventos no cotidiano de uma creche privada no bairro Jardim Botânico dialogando com a autora Maria Malta Campos (2009) em seu texto Critérios para um atendimento em creches que respeite os direitos fundamentais das crianças.

Acima de tudo, este breve estudo pretende mostrar que olhar é possível, o olhar além do olhar, o olhar carregado de sensibilidade, escuta e doação. 


\title{
Capítulo I - Um olhar para a legislação
}

\author{
Todos concordam: é necessário que a escola dê uma \\ boa base aos seus alunos. Mas acho que ninguém pensa em boa \\ base em termos de prazer, alegria, espírito comunitário, \\ sentimentos generosos e humanistas, sensibilidade artística. \\ Estas são coisas boas para a vida. \\ Rubem Alves
}

Educação é um dos direitos fundamentais das crianças. Da mesma forma, são garantidos por lei os direitos à saúde, à proteção, à integridade física e psicológica. Até mesmo brincar é um direito. A educação infantil é duplamente protegida pela Constituição Federal de 1988. Estar na escola tanto é direito das crianças, como é direito dos pais trabalhadores, direito esse conquistado após muita luta e resistência. Além da Constituição, o direito à educação infantil vem assegurado em outras normas nacionais, principalmente a Lei de Diretrizes e Bases da Educação Nacional - LDB, o Estatuto da Criança e do Adolescente - ECA e o Plano Nacional de Educação - PNE .

A constituição de 1988 traz em seu texto muitos avanços e conquistas mundiais no que diz respeito ao cuidado das crianças. Trazemos fragmentos desse texto para nossa análise, uma vez que a riqueza desses artigos trazem muitas possibilidades de reflexão. Eles falam sobre a responsabilidade da família, da sociedade e do Estado, como as três instâncias reais e formais de garantia dos direitos das Crianças e Adolescentes no nosso país.

É importante conhecermos e estudarmos esses artigos para que a gente entenda com isso, que a educação é um direito de todos e um dever das famílias. Toda a sociedade é responsável pela educação. Numa sociedade cada vez mais globalizada é importantíssimo assegurar a educação como um direito fundamental desde a infância. Pensar na importância de uma educação infantil de qualidade, para todas as crianças, nos ajuda a fortalecer a dignidade enquanto seres humanos que somos, pois somente através da educação que conseguiremos um equilíbrio, uma sociedade mais justa, igualitária, com mais direitos sociais, menos pobre e sobretudo mais solidária.

Destacamos dois artigos da Lei $n^{\circ} 9.394$ de 20 de dezembro de 1996. Essas leis estabelecem as diretrizes e bases da educação nacional e são orientações para as instituições de educação infantil: 
Art. 29. A educação infantil, primeira etapa da educação básica, tem como finalidade o desenvolvimento integral da criança até seis anos de idade, em seus aspectos físico, psicológico, intelectual e social, complementando a ação da família e da comunidade.

Art. 31. Na educação infantil a avaliação far-se-á mediante acompanhamento e registro do seu desenvolvimento, sem o objetivo de promoção, mesmo para o acesso ao ensino fundamental.

Há alguns anos, foi conquistado um importante avanço que retirou das creches a característica de Assistência Social. Creche não é só um lugar para os pais deixarem os filhos e poderem trabalhar, nem é depósito de crianças. Hoje, educação infantil é espaço de Educação, é espaço de desenvolvimento infantil.

Isso posto, analisamos o texto de Maria Malta Campos (BRASIL, 2009), intitulado Critérios para um atendimento em creches que respeito os direitos fundamentais das crianças. Esse documento está sendo veiculado pelo Ministério da Educação e pela Secretaria de Educação Básica, desde 1997, tendo sido ampliado em 2009. De maneira resumida, o documento sugere como orientação para as creches e préescolas brasileiras e idealiza:

- Nossas crianças têm direito à brincadeira;

- Nossas crianças têm direito à atenção individual;

- Nossas crianças têm direito a um ambiente aconchegante, seguro e estimulante;

- Nossas crianças têm direito ao contato com a natureza;

- Nossas crianças têm direito a higiene e à saúde;

- Nossas crianças têm direito a uma alimentação sadia;

- Nossas crianças têm direito a desenvolver sua curiosidade, imaginação e capacidade de expressão;

- Nossas crianças têm direito ao movimento em espaços amplos;

- Nossas crianças têm direito à proteção, ao afeto e à amizade;

- Nossas crianças têm direito a expressar seus sentimentos;

- Nossas crianças têm direito a uma especial atenção durante seu período de adaptação à creche;

- Nossas crianças têm direito a desenvolver sua identidade cultural, racial e religiosa;

Todos os direitos que foram assegurados para as crianças, citados a cima, se baseiam na concepção sócio interacionista do desenvolvimento humano, levando em consideração que os elementos sociais e também biológicos são essenciais para o desenvolvimento da criança, já que nós seres humanos, desde que nascemos vamos construindo nossas características, nosso modo de pensar e sentir o mundo que nos rodeia, nossos modos de agir.

Analisaremos alguns itens que destacamos para uma análise mais profunda. Todos ocupam o mesmo local de 
importância, porém alguns chamam mais a atenção, que são: direito à brincadeira; direito à atenção individual; direito a um ambiente aconchegante, seguro e estimulante; direito ao contato com a natureza; direito a desenvolver sua identidade cultural, racial $e$ religiosa.

As crianças necessitam de experiências para a construção de seus conhecimentos, seu desenvolvimento cognitivo, para se constituírem enquanto sujeitos, dentro de suas próprias características e visão de mundo. Para construírem significados, para além de interação, precisam brincar, explorar o meio que as rodeiam.

Entendemos que é nessa perspectiva que esse documento foi formulado, é a partir desses fundamentos que o trabalho educativo das creches deve se desenvolver. O tempo que as crianças passam dentro desses espaços de desenvolvimento infantil é muito longo, mais ou menos oito horas. Por isso é tão importante pontuar e orientar um trabalho bem planejado e organizado, respeitando os direitos das crianças. Esse documento é importante principalmente para pensarmos sobre os espaços. Os espaços para as crianças nas creches geralmente não são construídos de modo a traduzir o universo infantil.

É importante observar que geralmente na formulação de qualquer documento destinado à educação infantil a opinião dos educadores não é considerada, muitas vezes nem são citados. Acreditamos que essa exclusão dos professores no processo de construção do que idealizamos para um mundo melhor, passando pela escola, acarreta prejuízos às crianças, pois muitas vezes acabam não tendo acesso a espaços adequados para melhor desenvolverem sua aprendizagem. Nesse sentido, também é importante o trabalho dos engenheiros e de sua equipe de profissionais, que deve levar em conta as considerações do educador, pois não há ninguém mais capacitado profissionalmente para reconhecer o quanto um espaço físico limitado pode interferir de modo negativo na aprendizagem e em sua prática educativa.

Acreditamos que as propostas feitas por Maria Malta Campos nos ajudam a compreender que cabe à escola oportunizar várias situações destinadas à construção do conhecimento e ao desenvolvimento das crianças, para que cada vez mais elas conheçam e explorem atividades com o próprio corpo, com a imaginação, sendo sujeitos mais críticos, criativos, inteirando-se com os outros e consigo mesma. Quando a criança é o próprio sujeito de sua aprendizagem seu desenvolvimento psicológico e motor, também sua formação da personalidade, a construção da inteligência e aprendizagem se desenham de uma maneira mais lúcida, humana, menos excludente e castradora. 


\subsection{Nossas crianças têm direito à brincadeira}

Qual infância buscamos construir? Assegurar o direito à brincadeira é algo fundamental na educação infantil pois é pelo brincar que a criança promove seu desenvolvimento integral. Dar prioridade aos momentos lúdicos é buscar o desenvolvimento em toda sua plenitude, deixar a criança se expressar livremente através da brincadeira como uma oportunidade educativa que vai muito além dos conteúdos do currículo escolar tradicional. Criança que não brinca é criança triste, criança doente.

$\mathrm{O}$ direito à brincadeira está previsto nas leis mundiais e também nas leis brasileiras. Muitos documentos internacionais ressaltam sua importância, nos ajudam a entender a importância do brincar nos processos de aprendizagem da criança pequena. Em nosso país, temos um estatuto, o ECA, Estatuto da Criança e do Adolescente (BRASIL, 1990). Nele estabelecemos que o se divertir e brincar na infância são aspectos fundamentais do direito da criança e do adolescente à liberdade plena.

Além do ECA, no Brasil nós temos como documento orientador o Referencial Curricular Nacional para Educação Infantil (BRASIL, 1998). Nesse documento a brincadeira é assegurada como "forma particular de expressão, pensamento, interação e comunicação infantil”. Internacionalmente existe a Convenção sobre os Direitos da Criança, uma ação da Unicef (Fundo das Nações Unidas para a Infância), que diz que a criança tem direito ao tempo livre, tem direito ao repouso e principalmente direito à ações lúdicas e recreativas de acordo com sua própria idade.

Infelizmente ainda é lento o caminhar de nossa sociedade para entender a dimensão do brincar livre no desenvolvimento das crianças. Para atender as demandas dos adultos, as crianças geralmente brincam em espaços pequenos como aqueles que vemos nos shoppings. Nossa consciência sobre a importância do brincar ainda é baixa. Dizemos isso pensando também nos espaços escolares, uma vez que na escola não se brinca, pelo menos não livremente.

A maioria das instituições escolares deixa que as crianças brinquem apenas no horário determinado para que isso aconteça, geralmente no intervalo das aulas. Qual infância estamos construindo? Sem espaço para brincadeira e fantasias, são raras são as escolas que privilegiam o brincar na construção do saber. É no livre brincar que a criança desenvolve sua espontaneidade, é claro que precisamos assegurar que a criança esteja 
segura, porém as brincadeiras precisam trazer desafios e prazer, algo castrado pelas brincadeiras tidas como pedagógicas, com hora marcada para acontecer.

Segundo Oliveira (2000) a brincadeira é para além da recreação, o brincar é uma das maneiras mais complexas que a criança tem de comunicar-se consigo mesma e com o mundo, ou seja, o desenvolvimento acontece através de trocas recíprocas que se estabelecem durante toda sua vida. Assim, através do brincar a criança pode desenvolver capacidades importantes como a atenção, a memória, a imitação, a imaginação, ainda propiciando à criança o desenvolvimento de áreas da personalidade como afetividade, motricidade, inteligência, sociabilidade e criatividade. $\quad$ Pensando em Vygotsky (VYGOTSKY, 1998, 6. p.87) e nos estudos que falam sobre a interação com o outro e com o meio, a brincadeira infantil assume um lugar de destaque no processo de constituição do sujeito, rompendo com a tradicionalista forma de pensar de que a brincadeira apenas é uma atividade normal do universo infantil, algo instintivo. Pensar a brincadeira pela perspectiva vygotskyana é pensá-la como uma maneira de expressão de como a criança vê o mundo e, principalmente, de apropriação do mundo das relações, das atividades e dos papéis dos adultos.

Citando o Referencial

Curricular Nacional da Educação Infantil, vemos que:

O principal indicador da brincadeira, entre as crianças, é o papel que assumem enquanto brincam. Ao adotar outros papéis na brincadeira, as crianças agem frente à realidade de maneira não-literal, transferindo e substituindo suas ações cotidianas pelas ações e características d, o papel assumido, utilizando-se de objetos substitutos (BRASIL, 1998, p. 27, v.01).

É pela brincadeira que as crianças imaginam, se colocam no lugar do outro, planejam, vão se apropriando de novos saberes. A criança por intermédio da brincadeira, das atividades lúdicas, atua, mesmo que simbolicamente, nas diferentes situações vividas pelo ser humano, reelaborando sentimentos, conhecimentos, significados e atitudes.

Para CAMPOS (2009, p. 14), pensando em práticas educativas que privilegiem o direito à brincadeira no espaço de desenvolvimento infantil, ela nos orienta a questionar:

- Os brinquedos estão disponíveis às crianças em todos os momentos;

- Os brinquedos são guardados em locais de livre acesso às crianças;

- Os brinquedos são guardados com carinho, de forma organizada;

- As rotinas da creche são flexíveis e reservam períodos longos para as brincadeiras livres das crianças;

- As famílias recebem orientação sobre a importância das brincadeiras para o desenvolvimento infantil; 
- Ajudamos as crianças a aprender a guardar os brinquedos nos lugares apropriados;

- As salas onde as crianças ficam estão arrumadas de forma a facilitar brincadeiras espontâneas e interativas;

- Ajudamos as crianças a aprender a usar brinquedos novos

- Os adultos também propõem brincadeiras às crianças;

- Os espaços externos permitem as brincadeiras das crianças;

- As crianças maiores podem organizar os seus jogos de bola, inclusive futebol;

- As meninas também participam de jogos que desenvolvem os movimentos amplos: correr, jogar, pular;

- Demonstramos o valor que damos às brincadeiras infantis participando delas sempre que as crianças pedem;

- Os adultos também acatam as brincadeiras propostas pelas crianças.

A partir dessas ideias precisamos pensar em um currículo que privilegie a brincadeira, pensar a educação infantil é pensar em crianças livres para brincar, com materiais apropriados, com espaço, com qualidade. Educação infantil é espaço de interação, troca, busca de se reconhecer enquanto sujeito de sua própria aprendizagem, lugar onde a brincadeira é o centro do desenvolvimento.

\subsection{Nossas crianças têm direito à atenção individual}

A criança mais rápida, por exemplo, não é melhor do que a criança mais lenta. Todas as crianças devem ter as mesmas oportunidades, e a escola é um lugar privilegiado para que isso aconteça. Para darmos melhor condições de aprendizagens às crianças, devemos pensar em estratégias de aprendizagem diferentes. Precisamos parar de privilegiar determinadas qualidades.

As crianças aprendem com suas interações, a partir de suas experiências. Para compreendermos como é o desenvolvimento infantil precisamos observar o espaço que estão inseridas, quais são suas práticas sociais e principalmente de maneiras elas constroem seus significados, ou seja, como enxergam o mundo que as rodeiam. $\mathrm{O}$ pensamento é algo particular, como enxergarmos o mundo é extremamente particular, da mesma forma que aprendemos, ou seja, cada um aprende de um jeito, por isso atenção individual na escola é tão importante.

Quantos tipos de crianças temos em nossas escolas? Incontáveis. Uns são mais tímidos, outros mais agitados, uns mais expansivos, outros mais brincalhões, outros mais curiosos, outros mais introspectivos. Não há certo ou errado. Não há melhor criança ou pior criança. Infelizmente ainda buscamos uma homogeneização dos padrões de comportamento.

É tudo uma questão de saber trabalhar a diversidade nas escolas, uma questão de 
respeitar as diferenças. Precisamos, principalmente, respeitar o tempo que a criança aprende e se desenvolve, ele é particular. Cada ser humano é um ser individual, cheios de histórias e vivências únicas, cada um traz uma bagagem emocional dentro de si. Uma criança aprende de um jeito, outra criança aprende de outro jeito, não existe uma regra formada, o conhecimento não se constrói de maneira engessada pois todas as crianças tem seu próprio ritmo e tempo para se desenvolverem.

Para CAMPOS (2009, pg. 15/16), pensando em práticas educativas que respeitem o direito à atenção individual, valorizando sua própria forma de aprendizagem no espaço de desenvolvimento infantil, nos dá pistas sobre como agir:

- Chamamos sempre as crianças por seu nome;

- Observamos as crianças com atenção para conhecermos melhor cada uma delas; - O diálogo aberto e contínuo com os pais nos ajuda a responder às necessidades individuais da criança;

- A criança é ouvida;

- Sempre procuramos saber o motivo da tristeza ou do choro das crianças;

- Saudamos e nos despedimos individualmente das crianças na chegada e saída da creche;

- Conversamos e somos carinhosos com as crianças no momento da troca de fraldas e do banho;

Comemoramos os aniversários de nossas crianças;

- Crianças muito quietas, retraídas, com o olhar parado, motivam nossa atenção especial; - Aprendemos a lidar com crianças mais agitadas e ativas sem discrimina- las ou punilas;

- Aprendemos a lidar com preferências individuais das crianças por alimentos;

- Ficamos atentos à adequação de roupas e calçados das crianças nas diversas situações;

- Damos suporte às crianças que têm dificuldades para se integrar nas brincadeiras dos grupos;

- Procuramos respeitar as variações de humor das crianças;

- Procuramos respeitar o ritmo fisiológico da criança: no sono, nas evacuações, nas sensações de frio e calor;

- Crianças com dificuldades especiais recebem apoio para participar das atividades e brincar com os colegas;

- Nossas crianças têm direito a momentos de privacidade e quietude;

- Evitamos usar e que as crianças usem apelidos que discriminem outras crianças;

Procuramos analisar porque uma criança não está bem e encaminhá-la à orientação especializada quando necessário.

Com isso, entendemos que devemos incentivar as crianças, estimulá-las a buscar suas próprias conquistas e fazê-las fortes para cada vez mais se superarem, devemos aguçar a curiosidade sobre o mundo valorizando a brincadeira, as experimentações, criança aprende sendo criança, vivendo, cada uma no seu tempo e modo.

Não devemos forçar nenhum processo, muito menos acelerar os processos de aprendizagens, eles são individuais, porém forjados coletivamente, acontece 
naturalmente. Necessitamos doar amor, respeito, fazer um ambiente seguro e confortável para que as crianças se desenvolvam plenamente.

\subsection{Nossas crianças têm direito a um ambiente aconchegante, seguro e estimulante}

A escola é o lugar das interações, lugar das descobertas, lugar do desenvolvimento das aprendizagens. Para isso, é importante que os espaços sejam organizados de maneira desafiante às crianças no campo da cognição, social e, sobretudo motor. Para isso, precisamos que os espaços sejam aconchegantes, instáveis, adaptando-se a mudanças rapidamente, ou seja, permeáveis à ação da criança. O espaço de educação infantil precisa ser um espaço sujeito à constante modificação proposta pelas próprias crianças e pelos professores de acordo com as funções pretendidas. As crianças pequenas vivenciam de maneira muito intensa os espaços da escola, se fortalecem na dialética do espaço, na relação mútua entre elas e o local que brincam, os objetos, os móveis, a decoração, a alma do lugar e até mesmo o tamanho desse espaço. Criança precisa de espaço. Toda essa estrutura é fundamental na busca pela perspectiva lúdica que qualquer espaço de desenvolvimento infantil deve ter. Esse espaço deve ser um espelho, um espelho que reflete o meio social que a criança está inserida e ao mesmo tempo trazer novidades, novos conceitos de aprendizagem para que a criança desenvolva outras maneiras de ver o mesmo mundo. Gandini (1990, p.150) diz que o espaço reflete a cultura das pessoas que nele vivem de muitas formas e, em um exame cuidadoso, revela até mesmo as camadas distintas dessa influência cultural.

Conforme destacamos, a criança traz suas vivências do meio social em que está se desenvolvendo, é de lá que traz suas experiências, lá também deixa suas próprias marcas em sua forma de relacionar-se com o mundo. Entretanto, é a família sua primeira e principal referência básica de relação entre os sujeitos, apesar de todas as relações que ocorrem em todos os níveis sociais, mas para que seja de fato inclusivo, o espaço das crianças deve dar prioridade e deve fazer referência à história da criança e seu contexto e através disto promover a troca de saberes entre as crianças.

$\mathrm{Na}$

escola as crianças se desenvolvem, constroem amizades. É o lugar do afeto, espaço de convivência onde aprendemos respeito, um lugar rico em diversidades, para que a criança cresça e melhor aprenda cabe aos educadores e a comunidade escolar organizar o espaço de desenvolvimento infantil pensando no lado afetivo, valorizando o acolhimento as 
crianças, buscando estimular sua curiosidade e interesse.

Seguindo essa

lógica, aderindo à ideia exposta no Referencial Curricular Nacional para Educação Infantil (RCNEI), é preciso levar em conta que:

$\mathrm{Na}$ área externa, há que se criar espaços lúdicos que sejam alternativos e permitam que as crianças corram, balancem, subam, desçam e escalem ambientes diferenciados, pendurem-se, escorreguem, rolem, joguem bola, brinquem com água e areia, escondam-se etc. (BRASIL, 1998a, p.69).

Conforme já pontuamos, criança também precisa de espaço para desenvolver-se com qualidade. Ainda pensando na infraestrutura e organização dos espaços, vemos os Parâmetros Básicos de Infraestrutura para Instituições de Educação Infantil que recomendam:

[...] que a área mínima para todas as salas para crianças de 0 a 6 anos contemple $1,50 \mathrm{~m} 2$ por criança atendida considerando a importância da organização dos ambientes educativos e a qualidade do trabalho. Recomenda-se que a metragem das salas seja a mesma, independentemente da faixa etária, possibilitando alterações nos agrupamentos, de acordo com a demanda da comunidade (BRASIL, 2006, p.27).

O espaço criado para a criança deve então se organizar de acordo com faixa etária, quantidade de crianças, e essa organização deve estar sendo propondo desafios cognitivos e motores que a farão avançar no desenvolvimento de suas potencialidades. O espaço deve estar povoado de objetos que retratem a cultura e o meio social em que a criança está inserida.

Para CAMPOS (2009, pg. 17), pensando em práticas educativas que respeitem a qualidade do espaço voltado para o desenvolvimento infantil, ela pontua os seguintes critérios de organização para sua creche:

-Arrumamos com capricho e criatividade os lugares onde as crianças passam o dia ;

- Nossas salas são claras, limpas e ventiladas;

- Não deixamos objetos e móveis quebrados nos espaços onde as crianças ficam;

- Mantemos fora do alcance das crianças produtos potencialmente perigosos;

As crianças têm lugares agradáveis para se recostar e desenvolver atividades calmas;

- As crianças têm direito a lugares adequados para seu descanso e sono;

- Nossa creche demonstra seu respeito às crianças pela forma como está arrumada e conservada;

- Nossa creche sempre tem trabalhos realizados pelas crianças em exposição;

- Quando fazemos reformas na creche nossa primeira preocupação é melhorar os espaços usados pelas crianças;

Quando fazemos reformas tentamos adequar a altura das janelas, os equipamentos e os espaços de circulação às necessidades de visão e locomoção das crianças;

Nossa equipe procura desenvolver relações de trabalho cordiais e afetivas; 
Procuramos tornar acolhedor o espaço que usamos para receber e conversar com as famílias;

- Procuramos garantir o acesso seguro das crianças à creche;

- Lutamos para melhorar as condições de segurança no trânsito nas proximidades da creche.

\subsection{Nossas crianças têm direito ao contato com a natureza}

Vivemos em uma sociedade capitalista onde a lógica do consumo está cada vez crescendo mais. Com isso, os brinquedos de plástico ganham muita amplitude. As crianças, para comodismo dos pais, muitas vezes brincam apenas com objetos eletrônicos e pouco interagem com outras crianças. Percebemos também que na construção das cidades, muitos espaços, inclusive em algumas escolas, são cimentados ou recobertos com grama sintética. Até mesmo os vasos de flores e plantas naturais são substituídos pelos artificiais, pois dispensam água, o nosso cuidado e por consequência economizam nosso tempo.

Todas essas questões são muito prejudiciais às crianças. Problematizamos que os espaços infantis estão muito voltados para conteúdos, pouco valorizam o ato de brincar, não dosam, ao longo do dia, momentos de atividades internas e outras atividades ao ar livre. Muitas vezes nem possuem em sua configuração estrutural um espaço externo de qualidade. Ainda seguimos transmitindo às crianças uma visão do planeta como fonte inesgotável de onde nós seres humanos podemos extrair e extrair; e da natureza como simples matéria-prima morta para a produção de mercadorias.

Como as práticas pedagógicas reproduzem essa visão de mundo? Se ensinamos a ver a natureza com fonte inesgotável apenas de matéria-prima estruturando toda a lógica do consumo, como, nessas circunstâncias, ensiná-las a amar e a preservar a natureza? Creches e pré-escolas são espaços privilegiados para aprender-ensinar porque lá as crianças colhem suas primeiras sensações, impressões, sentimentos do viver. Sendo assim, a dimensão ambiental não poderia estar ausente de toda a estrutura do ensina da educação infantil, o acesso à natureza e o ensino sobre sua valorização deveria ocupar um lugar central no processo de desenvolvimento infantil.

Acontece que a escola ainda não aprendeu a trabalhar a diversidade, com isso também não valoriza a diversidade biológica. Nem sequer nos percebemos no mundo como seres biológicos, animais, nos vemos como seres superiores cuja natureza está ao nosso serviço. Com isso vamos provocando danos profundos ao meio que fazemos parte. 
Em 1988, quando foi aprovada a atual Constituição Brasileira, a Educação Infantil passou a ser um direito das crianças. Mas, se elas até os cinco/seis anos geralmente pouco visitam o área externa, o pátio, e, desde muito pequenas têm o direito de permanecer por apenas pouquíssimas horas ao ar livre, à luz do sol, passam a maior parte do tempo brincando sobre cimento ou grama sintética; e se as janelas da sala onde permanecem o restante do tempo não permitem a visão do mundo lá de fora; se assim os dias vão se sucedendo, será que nossas crianças sabem o que é a liberdade? O que foi conquistado como direito, em realidade constitui certa forma de prisão.

O movimento de dizer não à destruição da vida na Terra implica práticas pedagógicas que assumam a educação como prática da liberdade (FREIRE, 1996), precisamos focar nas interações afetivas e criativas mas que essas relações também tenham alguma intencionalidade política, pois sem criticidade não há ensino.

Acreditando que são estes os caminhos que nos levarão a dizer não ao consumismo e ao desperdício de recursos naturais, renováveis e não renováveis CAMPOS (2009, pg. 18), propõe em sua creche:

- Nossa creche procura ter plantas e canteiros em espaços disponíveis;

- Nossas crianças têm direito ao sol;

- Nossas crianças têm direito de brincar com água;

- Nossas crianças têm oportunidade de brincar com areia, argila, pedrinhas, gravetos e outros elementos da natureza;

- Sempre que possível levamos os bebês e as crianças para passear ao ar livre ;

- Nossas crianças aprendem a observar, amar e preservar a natureza;

- Incentivamos nossas crianças a observar e respeitar os animais;

- Nossas crianças podem olhar para fora através de janelas mais baixas e com vidros transparentes;

- Nossas crianças têm oportunidade de visitar parques, jardins e zoológicos;

- Procuramos incluir as famílias na programação relativa à natureza.

\subsection{Nossas crianças têm direito a desenvolver sua identidade cultural, racial e religiosa}

Na escola, desde pequenas, as crianças já começam a conhecer seu corpo, suas semelhanças e as diferenças entre ela e as outras crianças. A partir desse entendimento, se percebem inseridas em grupos, classificam, escolhem com quem brincam e com quem se relacionam, têm suas preferências por brinquedos, brincadeiras, pessoas. Pensando nisso, percebemos o quanto a escola precisa urgentemente começar a trabalhar com as crianças, mesmo as menores, questões sobre diferença e em especial, as relacionadas ao pertencimento racial, não só com as crianças, mas com as famílias e comunidade. 
Assim sendo, e de acordo com o Plano Nacional de Implementação da Lei n 10.639/2003,

O papel da educação infantil é significativo para o desenvolvimento humano, a formação da personalidade, a construção da inteligência e a aprendizagem. Os espaços coletivos educacionais, nos primeiros anos de vida, são espaços privilegiados para promover a eliminação de qualquer forma de preconceito, racismo e discriminação, fazendo com que as crianças, desde muito pequenas compreendam e se envolvam conscientemente em ações que conheçam, reconheçam e valorizem a importância dos diferentes grupos étnico raciais para a história e cultura brasileiras. (BRASIL, 2004, p.17).

Partindo da referência da pesquisa de documentos oficiais como a LDB, os PCN e RCNEI, as DCNEI, vimos que Lei 10.639/03 torna obrigatório nas escolas públicas e particulares do Brasil o ensino da História e Cultura Afro-brasileira e Africana visando promover um melhor desenvolvimento na formação da identidade das crianças, levando em consideração as diferenças étnico raciais, incluindo as crianças negras num lugar de relevância para a cultura e a história da sociedade brasileira.

Sabemos que existe preconceito dentro das escolas, mesmo as destinadas à educação infantil, porém esse preconceito é velado, disfarçado, como acontece na sociedade como um todo. É fundamental que o professor esteja formado para trabalhar com as diversidades na escola. A partir do processo de construção de respeito e valorização à diversidade, sobretudo a etnicorracial, cultural e social, haverá uma mudança de mentalidade estrutural na sociedade, começando pelas crianças que em alguns casos já indicam a reprodução de certos discursos racistas, homo fóbicos, etc.

Todas as crianças precisam de respeito e acolhimento, não importa quais crenças, religiões ou etnias sejam oriundas. Desde pequenas também precisam aprender a respeitar e a conviver com os colegas, naturalmente diferentes uns dos outros, conviver com a diversidade. Os professores precisam de um maior preparo para lidar com essas questões, uma vez que o senso comum discursado nas escolas é ensinar que "aqui ninguém é diferente", refletindo uma lógica de homogeneização dos corpos pois somos todos

diferentes. É fundamental que saibamos explicar para nossas crianças que as diferenças fazem parte da história da humanidade e não significam inferioridade, trabalhando desde o início da identidade das crianças negras e ensinando as crianças brancas a romperem com o racismo já enraizado desde novos. 
Para CAMPOS (2009, pg. 27), pensando em práticas educativas que respeitem e valorize as diversidades presentes no espaço escolar, determina em seus critérios para educação infantil que nossas creches assegurem:

- Nossas crianças têm direito a desenvolver sua identidade cultural, racial e religiosa;

- Nossas crianças têm direito a desenvolver sua autoestima;

- Meninos e meninas têm os mesmos direitos e deveres;

- Nossas crianças, negras e brancas, aprendem a gostar de seu corpo e de sua aparência;

- Respeitamos crenças e costumes religiosos diversos dos nossos;

- Nossas crianças não são discriminadas devido ao estado civil ou à profissão de seus pais;

- A creche é um espaço de criação e expressão cultural das crianças, das famílias e da comunidade;

- Nossas crianças, de todas as idades, participam de comemorações e festas tradicionais da cultura brasileira: carnaval, festas juninas, natal, datas especiais de nossa história;

- Nossas crianças visitam locais significativos de nossa cidade, sempre que possível: parques, museus, jardim zoológico, exposições

- Nossas crianças visitam locais significativos do bairro, sempre que possível: a padaria, uma oficina, a praça, o corpo de bombeiros, um quintal

- Estimulamos os pais a participar ativamente de eventos e atividades na creche

Isto posto, sobre os objetivos gerais da educação infantil o Referencial Curricular Nacional para Educação Infantil (1998, vol. 01, p.63) ressalta que as práticas educativas desenvolvidas nas instituições de educação infantil devem ter como objetivo o desenvolvimento das crianças com a perspectiva de construírem as seguintes capacidades:

- Desenvolver uma imagem positiva de si, atuando de forma cada vez mais independente, com confiança em suas capacidades e percepção de suas limitações;

- Descobrir e conhecer progressivamente seu próprio corpo, suas potencialidades e seus limites, desenvolvendo e valorizando hábitos de cuidado com a própria saúde e bem-estar;

- Estabelecer vínculos afetivos e de troca com adultos e crianças, fortalecendo sua autoestima e ampliando gradativamente suas possibilidades de comunicação e interação social;

- Estabelecer e ampliar cada vez mais as relações sociais, aprendendo aos poucos a articular seus interesses e pontos de vista com os demais, respeitando a diversidade e desenvolvendo atitudes de ajuda e colaboração;

- Observar e explorar o ambiente com atitude de curiosidade, percebendo-se cada vez mais como integrante, dependente e agente transformador do meio 
ambiente e valorizando atitudes que contribuam para sua conservação;

- Brincar, expressando emoções, sentimentos, pensamentos, desejos e necessidades;

- Utilizar as diferentes linguagens (corporal, musical, plástica, oral e escrita) ajustadas às diferentes intenções e situações de comunicação, de forma a compreender e ser compreendido, expressar suas ideias, sentimentos, necessidades e desejos e avançar no seu processo de construção de significados, enriquecendo cada vez mais sua capacidade expressiva;

- Conhecer algumas manifestações culturais, demonstrando atitudes de interesse, respeito e participação frente a elas e valorizando a diversidade

Com isso, a análise do texto Critérios para um atendimento em creches que respeite os direitos fundamentais das crianças de Maria Malta Campos nos conforta, pois, todas essas propostas caminham para um lugar seguro e confortável para que cada vez mais as crianças interajam de maneira sadia e mais humana e afetuosa. Vimos que essas orientações respeitam os princípios éticos, políticos e estéticos orientados pela Diretrizes Curriculares para a Educação Infantil (BRASIL, 2009). Valorizam a autonomia da criança, a solidariedade e do respeito ao bem comum, ao meio ambiente e às diferentes culturas, identidades e singularidades. Ou seja, entende que a educação precisa respeitar a valorizar as diferenças. Essas propostas promovem a cidadania, ensinando as crianças desde pequenas a exercerem a criticidade e o respeito ao outro, que é diferente de mim. Principalmente essas orientações valorizam as sensibilidades, da criatividade tão importante na vida humana, a brincadeira, produto essencial para a infância e visa promover a liberdade de expressão nas diferentes manifestações artísticas e culturais das crianças.

Assim, esse texto nos norteia para pensarmos numa educação infantil e em práticas pedagógicas que levem em conta em sua concepção e administração, o desenvolvimento da criança, valorizando a diversidade social e cultural e os conhecimentos que pretendemos universalizar. Esse lugar de desenvolvimento infantil deve ser mais democrático, mais afetivo, menos castrador, uma vez que a aprendizagem se dá, como apontam Piaget e Vygotsky através da interação com o meio, já que o papel das creches é de promover essas interações que sejam feitas de maneira mais respeitosa e humanizada. 


\section{CAPÍTULO II - O LUGAR DO OLHAR}

"Há muitas pessoas de visão perfeita

Que nada veem...

$\mathrm{O}$ ato de ver não é coisa natural.

Precisa ser aprendido".

Rubem Alves

A Fotografia como objeto carregado de história exige um olhar cuidadoso tanto para a cena quanto para sua história.

Pelo fato de considerar a fotografia como exercício precioso para um olhar mais sensível decidi fotografar a exposição de cartazes da minha turma de especialização. A exposição proposta pelas professoras Nazareth Saluto e Denise Gusmão das respectivas disciplinas Cotidiano de Trabalho em Creches e Pré-Escolas e A criança e a Cultura teve como objetivo ao final do semestre, revelar a trajetória das alunas até a conclusão do curso, como se tornaram professoras, o que as motivaram a estar no curso e como estavam saindo. Iniciei despretensiosamente a sessão de fotografias, sem compromisso, como disse, apenas pelo exercício do olhar, mas ao olhar eu vi além.

Esse olhar motivou-me a escrever sobre a proposta como trabalho de conclusão da disciplina A Criança e a Cultura levando-me a pesquisar o conceito de exotopia, que significa desdobramento de olhares a partir de um lugar exterior. Esse lugar exterior permite, segundo Bakhtin, que se veja do sujeito algo que o próprio sujeito nunca pode ver. Essa atitude comporta um olhar comprometido e ético.

Tal movimento, que Bakhtin caracterizou como exotopia, diz respeito ao processo envolvido nas relações humanas, na criação estética ou na pesquisa científica na área de ciências humanas segundo o qual procuro me colocar no lugar do outro, compreender como a partir de sua visão que é única ele se coloca em relação ao mundo, para, depois, retornar a minha posição, acrescida da experiência do outro, mas acrescentando ao outro o que ele não vê, pois é como o vejo ao fim do percurso que lhe dá uma visão que ele de si não tem. Se sou eu que finalizo, dou uma visão acabada ao outro, inversamente, é o outro que pode dar-me o acabamento, situar-me de meu lugar no mundo também, num processo de trocas recíprocas e mutuamente esclarecedoras. E é ele que me dá o que somente sua posição permite ver e entender ${ }^{1}$.

\footnotetext{
${ }^{1}$ Essas ideias são reflexões a partir do texto de Jobim e Souza e Gusmão, 2008.
} 
Esse trabalho tem uma relação com o tema proposto nesta monografia pois entendo que é no lugar da exotopia que olharei mais sensivelmente o universo infantil.

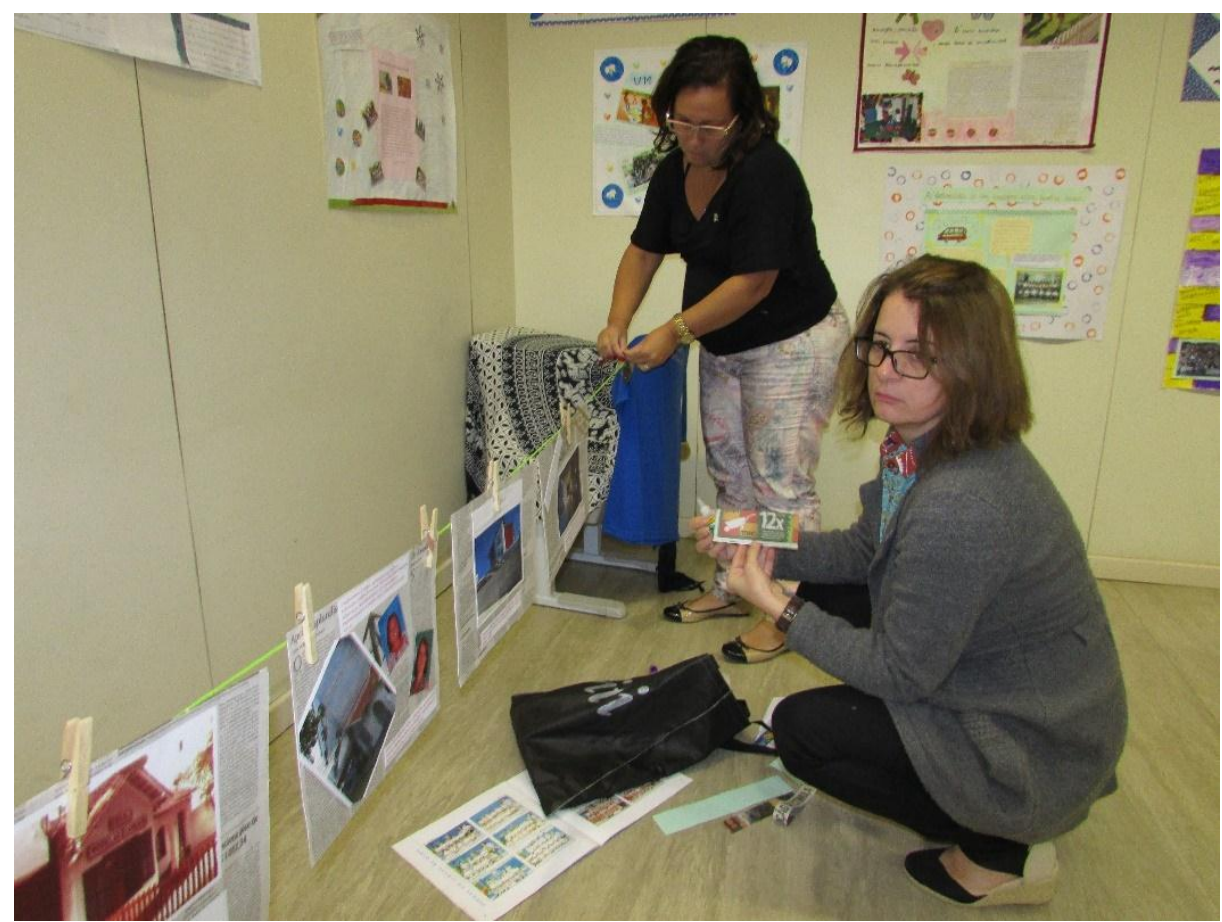

Foto 1 - Alunas organizando um varal com fotos que mostram suas trajetórias de vida

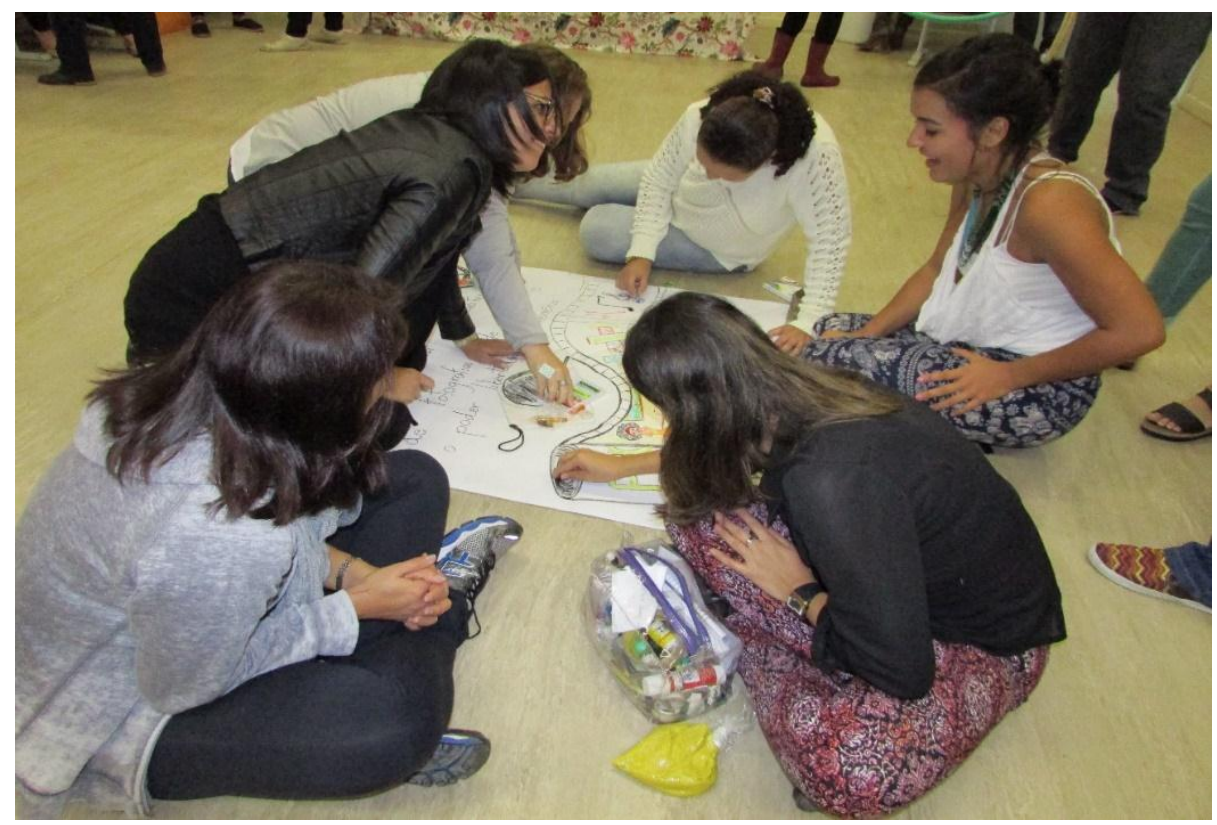

Foto 2 - Alunas produzindo um cartaz para ilustrar a exposição 


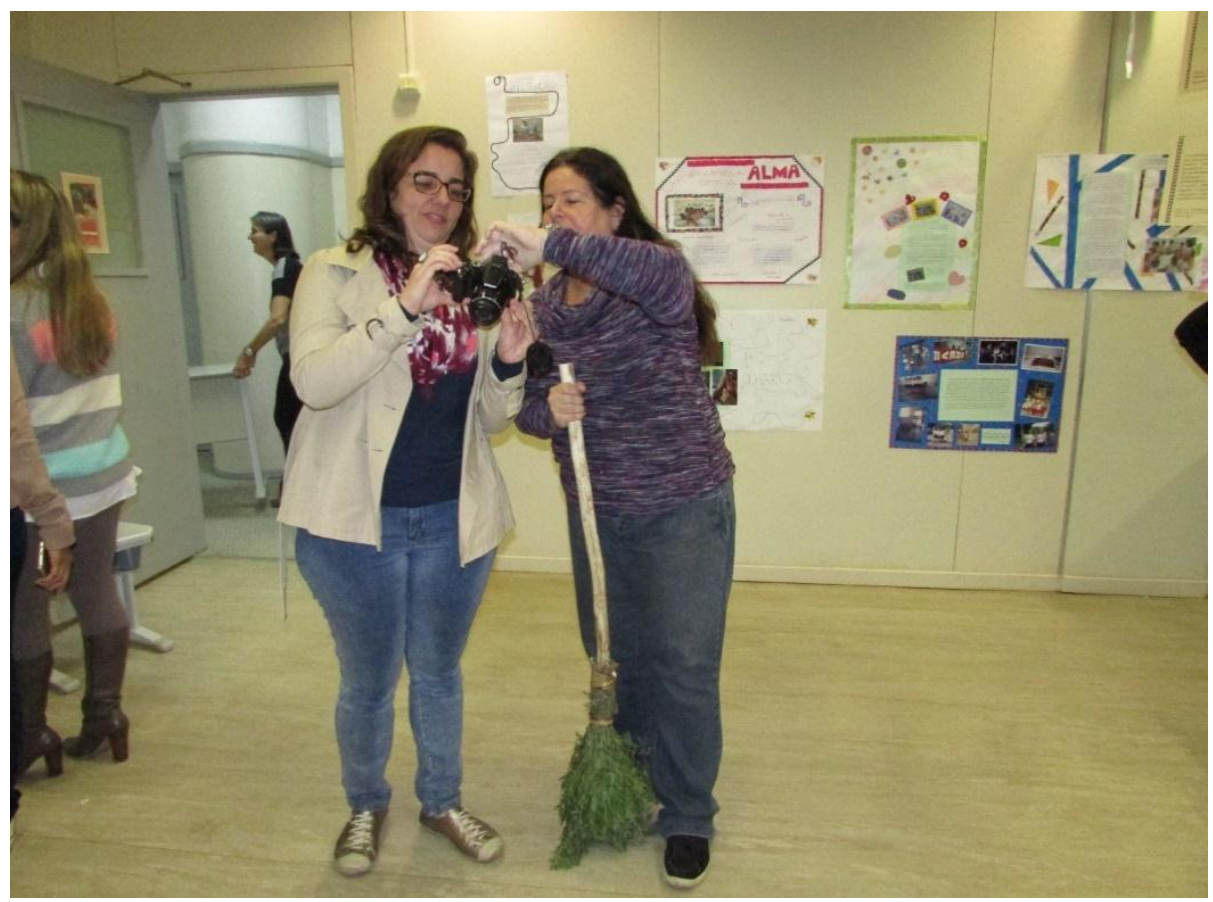

Foto 3 - As professoras Alexandra Pena e Denise Gusmão preparando a máquina fotográfica

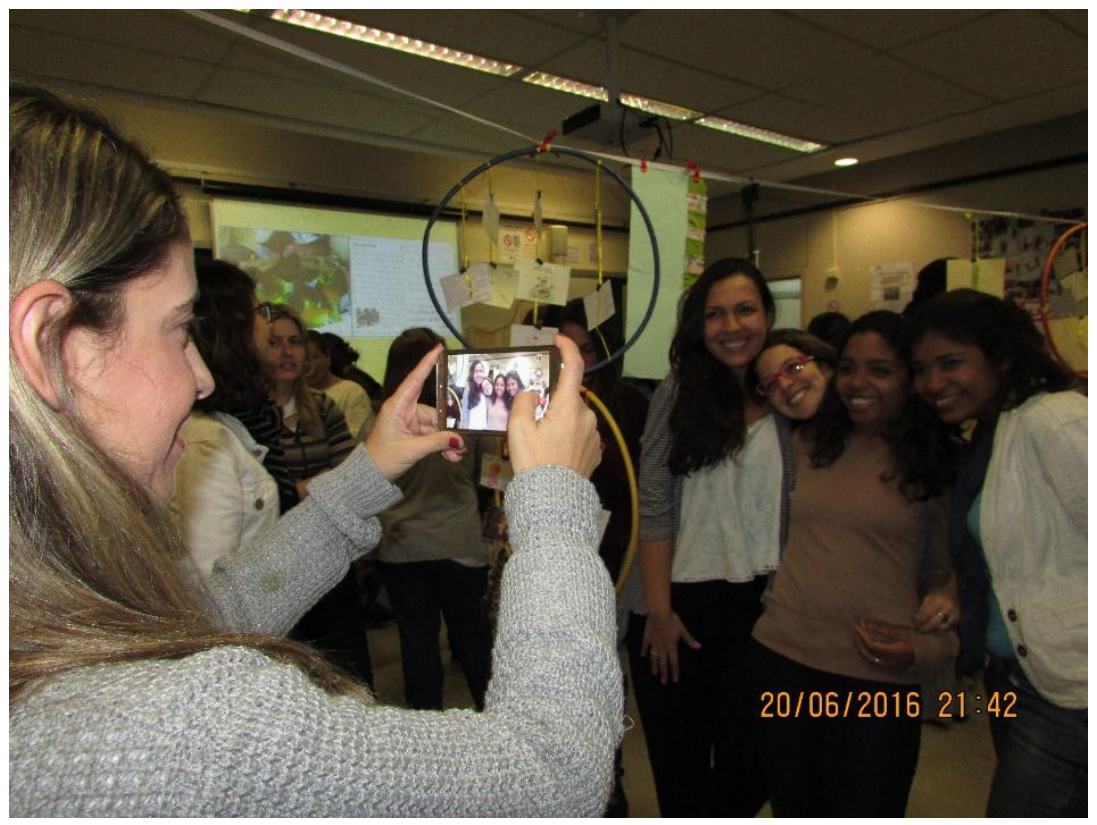

Foto 4 - Aluna fotografando um grupo de alunas da turma 


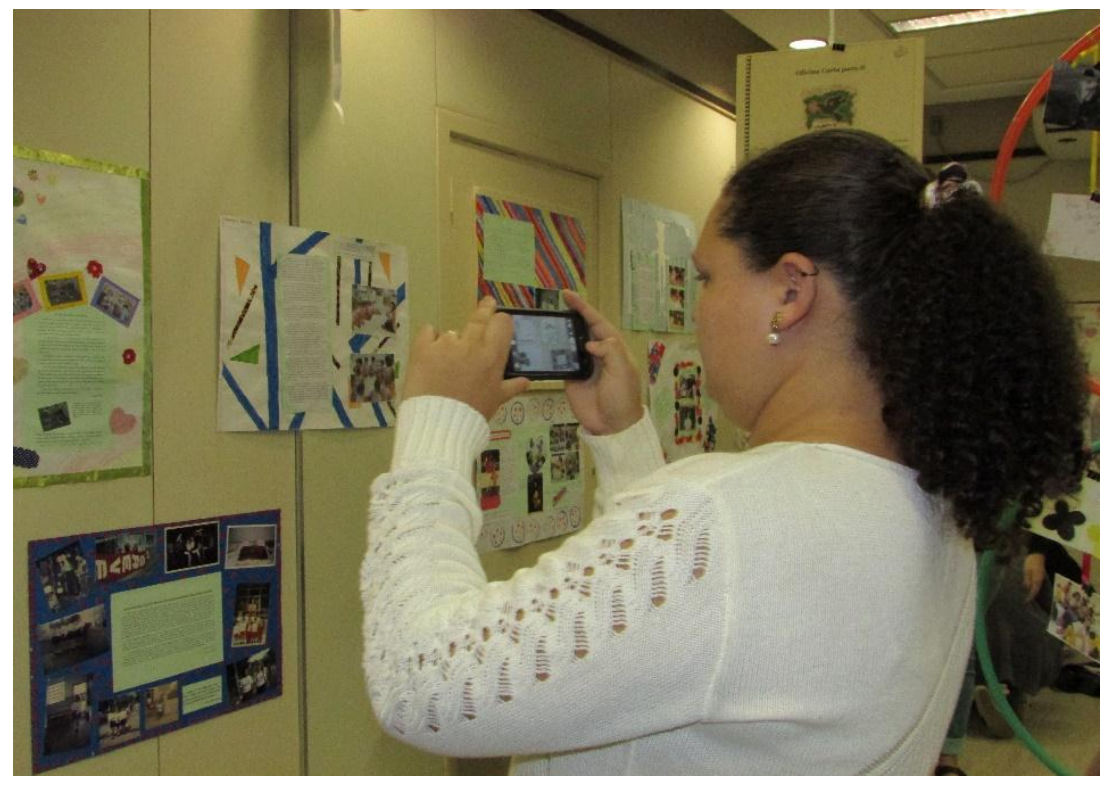

Foto5 - Aluna fotografando cartazes

Juntamente com o senso de que a fotografia nos faz cogitar sobre as possibilidades diversas de leitura da imagem revelada, a fotografia também fala do objeto carregado de história. Dentro de um contexto espacial e temporal, a imagem revela emoções, sensações, hábitos e significados de uma época. Os teóricos Benjamin (1987) e Pasolini (1990) ampliam essa discussão refletindo sobre "a linguagem pedagógica das coisas", expressão criada por Pasolini, que procura denominar a capacidade dos objetos, como signos linguísticos, de expressar uma outra dimensão da realidade.

Neste capítulo eu trouxe o lugar do olhar para mostrar a relevância do exercício de exotopia no olhar para a criança pois ao olhar o universo da sala de aula no cotidiano infantil entendi a necessidade do olhar atento a criança e seus direitos. A criança que brinca, que precisa de um espaço de qualidade, de contato com a natureza, de atenção individual e constituição da identidade, precisa especialmente desse olhar atento que privilegia a história de cada um. 


\section{CAPÍTULO III - UM OLHAR À CRIANÇA}

A educação infantil, primeira etapa da educação básica, contempla crianças com idade entre 0 e 5 anos. De acordo com a Lei de Diretrizes e Bases (BRASIL, 1996) essa etapa é dividida, assim: crianças de 0 a 3 anos frequentam a creche e de 4 a 5 a préescola. Embora cada segmento tenha suas especificidades, não há uma diferença na proposta pedagógica, já que a creche e a pré-escola têm objetivos parecidos (BRASIL, 1998, BRASIL, 2009).

É nessa etapa da vida escolar que as crianças adquirem suas principais conquistas para a vida. Portanto as instituições pedagógicas trabalham de forma a favorecer o desenvolvimento intelectual, físico, cognitivo e social da criança. Nesse contexto, como vimos nas orientações de CAMPOS (2009), mas também em outros documentos (BRASIL, 1990, 1998, 2009), o brincar se torna importante, peça

fundamental para o melhor desenvolvimento da criança, já que contribui para o desenvolvimento das habilidades motoras, cognitivas, afetivas e sociais.

Entendendo que as atividades lúdicas exercem um poder sobre as crianças, que proporciona aprendizagem de forma prazerosa e eficaz, analisamos atividades propostas a crianças de um grupo de maternal I, com crianças de 2 a 3 anos, numa creche privada situada que atende a crianças de bairro de classe média alta no município do Rio de Janeiro.

A creche faz parte do PEA-UNESCO desde março de 2000 devido à implantação do Programa em Valores Humanos Universais que objetiva substituir a violência por condutas de paz. Segundo a proposta pedagógica da instituição, tem como missão, com um olhar construtivista, contribuir para o desenvolvimento das potencialidades físicas e psíquicas das crianças tornando - as conscientes do seu papel e responsabilidades.

A instituição funciona com o sistema de rodízio de espaços. A cada meia hora os grupos revezam os espaços. Em alguns momentos esses espaços são compartilhados por mais de uma turma. Falo do lócus de professora dessa instituição. Fiz as considerações na turma de outra professora ao longo de duas semanas nos meus horários de aulas extras e em alguns momentos de compartilhamento de espaços. São três aulas extras que o meu grupo possui ao longo de quatro dias da semana com duração de trinta minutos cada, possibilitando cinco horas de análise direta, o restante das horas de observação foram completadas ao longo dos momentos de compartilhamento de espaços. 
O grupo observado tem algum contato comigo tendo em vista que jantam com o meu grupo e ficam comigo por um curto período de tempo ao final do dia. Acredito que o fato contribuiu para o estudo, pois não estranharam a minha presença.

\section{*Atividade 1 - Direito à brincadeira}

\section{(Brincadeiras com tecidos diversos na sala de psicomotricidade)}

De acordo com Brougère (1997) o brincar e as influências do mundo andam lado a lado e não podem ser separados. O brincar não é uma atividade interna dos indivíduos, mas é cheio de significado social. Para o autor a criança é um ser social e aprende a brincar. Nesse contexto entende-se que a brincadeira é um tipo de aprendizagem social. A criança não brinca numa ilha deserta. Ela brinca com as substâncias materiais que lhes são propostas, ela brinca com o que tem na mão e com o que tem na cabeça (BROUGÈRE,1997, p.105).

Conforme pontuamos no capítulo 1 , as crianças demonstram interação com o ambiente que acercam desde os primeiros meses de vida e o estimulo dado a ela, junto com suas características pessoais, vai ser fundamental seu desenvolvimento. Por isso a brincadeira é tão importante. O universo lúdico é uma das principais possibilidades de aprendizagem das crianças. As atividades lúdicas podem ser: dançar, cantar, pintar, brincar de teatro de fantoches, desenhar jogar, ou qualquer outro tipo de atividade que permita uma inteiração com o ambiente que o cerca e com o outro. Observei uma atividade no tom de brincadeira com tecidos na sala de psicomotricidade. A sala é usada para fins diversos com todos os grupos da escola. Tem como características físicas principais o chão atapetado (tipo tatame), televisão, aparelho de DVD e materiais próprios para as aulas específicas: yoga, psicomotricidade, atividades corporais, educação física (dias chuvosos), visualização de filmes e atualmente também para um grupo dormir após o almoço no período de uma hora. Ao chegarem à sala a professora convidou as crianças para brincarem com tecidos diversos livremente, pois já conheciam a proposta. Ela tirou os tecidos de uma bolsa dizendo que era uma bolsa mágica e foi lançando-os para o ar. As crianças deixavam os tecidos caírem no tapete e aos poucos iam se apropriando da proposta. Inicialmente fizeram um pano comprido de canoa. Enquanto alguns entraram na canoa duas crianças disseram: - "Eu sou o jacaré", morderam o tecido (canoa) e tentaram pegar o pé de quem estava dentro. Um deles que representava o jacaré disse: - "Eu como crianças! Eu não gosto de vocês na minha lagoa!” E imitou uma risada como a da bruxa. De repente uma criança que estava dentro da "canoa" empurrou uma 
das crianças que representava o jacaré e disse: - "Para de morder a canoa". A criança empurrada ficou deitada, a que empurrou foi até ela e disse: - "Levanta".

Uma criança quis o pano que era a canoa e começou a puxar, como ninguém cedeu ela disse: - "Eu quero brincar com isso! Da licença Maria Luisa ${ }^{2}$ ". Continuaram sem dar atenção então ela dirigiu-se à professora e disse: - "Patrícia eu quero brincar com o pano da canoa" a professora sugeriu que ela procurasse outro pano pela sala. Logo que encontrou um que a agradou voltou correndo até a professora e solicitou: - "Patrícia faz uma capa da Branca de Neve para mim".

Após algum tempo uma criança sugeriu: - "Vamos fazer uma cabana pessoal?" ninguém levantou da "canoa" então ele dirigiu - se a professora e disse: - "Patrícia eu quero fazer uma cabana" a professora orientou - o a falar com os amigos. Ele voltou ao grupo, começou a cantar a música do indiozinho e foi enrolando o tecido "obrigando" a quem estava sentado a levantar - se, todos levantaram e começaram a cantar junto com ele mas somente uma criança aceitou a proposta de fazer a cabana.

Sabemos que a criança gosta mesmo é de brincar, e esse direito é garantido por lei. É difícil encontrar alguém que desminta que o brincar oferece vantagens em todas as suas formas, proporcionando alegria e divertimento. Segundo Almeida (2004) o brincar desenvolve a criatividade, a competência intelectual, a força e a estabilidade emocionais, e sentimentos de alegria e prazer: o hábito de ser feliz.

É através do brincar que a criança se percebe e compreende a realidade em que está inserida. A brincadeira é uma forma gostosa que a criança encontra de se movimentar. É brincando que a criança desenvolve suas habilidades, é brincando que a criança socializa, aprende a se relacionar com o outro, desenvolve o aspecto físico e mental, além de se tornar mais afetiva e ativa.

\section{*Atividade 2 - Direito ao movimento em espaços amplos e ao ar livre}

(Brincadeiras com carros, bicicletas e motos no pátio)

Muitas vezes não se percebe a importância que o espaço e sua organização têm para a formação, desenvolvimento e aprendizagem da criança pequena, pensam o espaço como algo descolado das práticas pedagógicas, sendo apenas um papel de fundo, invisibilizando o grande significado que tem no processo educativo, pois o espaço além de orientar a prática educativa também facilita e qualifica o processo.

\footnotetext{
${ }^{2}$ Os nomes usados são fictícios.
} 
De acordo com o Referencial Curricular Nacional para a Educação Infantil (BRASIL, 1998, p. 69):

O espaço na instituição de educação infantil deve propiciar condições para que as crianças possam usufruí-lo em benefício do seu desenvolvimento e aprendizagem. Para tanto, é preciso que o espaço seja versátil e permeável à sua ação, sujeito às modificações propostas pelas crianças e pelos professores em função das ações desenvolvidas.

Destacamos a importância dos espaços físicos internos e externos serem organizados com o propósito de favorecer o desenvolvimento e aprendizagem, sempre adequados à faixa etária da criança. A importância de espaços físicos também está abordada nas Diretrizes Curriculares Nacionais da Educação Básica (BRASIL, 2013, p. 93)

\footnotetext{
A criança deve ter possibilidade de fazer deslocamentos e movimentos amplos nos espaços internos e externos às salas de referência das turmas e à instituição, envolver-se em explorações e brincadeiras com objetos e materiais diversificados que contemplem as particularidades das diferentes idades [...]" Os documentos legais nos colocam a importância de espaços organizados para que favoreçam aprendizagem em diferentes vivências, estimulem e desenvolvam a criança
}

Esse pátio analisado é aberto, portando usado somente nos dias ensolarados ou nublados. É um corredor relativamente pequeno onde as crianças brincam com carros, bicicletas, motos, de desenhar no chão com giz de quadro e bolinha de sabão. No dia da observação a professora ofereceu ao grupo os carros. As crianças brincavam e de repente uma delas começou a brincar também de "Sítio do Pica-pau Amarelo".

Segundo a professora, desde que ela apresentou a história e o CD de músicas do Sítio eles brincam que são os personagens e que estão no sítio. Ela explicou que cada um foi se autonomeando um personagem. Foi notório que a brincadeira seduziu o grupo. Logo um disse: - "Estou mandando a Cuca embora, mas ela não sai daqui do sítio!”. Uma criança apareceu imitando um som que outras identificaram como sendo da Cuca, então uma criança disse: - “Ai meu Deus! Vamos fugir rápido!”. Pouco depois a mesma criança parou com a moto e disse: - "Pedrinho, Pedrinho eu esqueci a minha chave!" A criança que era o Pedrinho disse: - "Vamos lá pegar a minha chave, eu não esqueci!" e pegou simbolicamente uma chave da parede para ele e depois outra para a outra criança.

A criança que fez o papel de Cuca continuou imitando os gritos da personagem e bateu o carro no das outras crianças tentando prende-las em um canto. Então o "Pedrinho" disse: - "Ai! Estamos presos na gaiola!". Depois de um "pega-pega" entre a Cuca e as 
outras crianças, uma delas conseguiu empurrar o carro da Cuca e outra disse: - "A Cuca está indo embora! Vamos atrás dela!” . A mesma zangou-se com a que empurrou a Cuca e disse: - "Não pode empurrar a nossa amiga Cuca! A Cuca é nossa amiga!".

Após algum tempo o grupo organizou uma espécie de casa com os carros e mudaram um pouco o enredo da brincadeira. A criança que fez o personagem da Cuca transformou-se espontaneamente no Ben 10 e ao tentar entrar na casa uma criança falou: - “ Está muito cheio aqui! Você é muito grande para entrar aqui na casa!”. Depois de algum tempo deixou ele entrar. Em alguns momentos eles misturaram as brincadeiras falando que a casa era do sítio e chamando uns aos outros pelos nomes dos personagens. Neste evento chamou-me atenção a interação entre as crianças, como elas compartilharam, negociaram e criaram cultura entre si. Percebi claramente a apropriação de informações do mundo adulto bem como a criação no contexto da cultura de pares. A noção de reprodução interpretativa, proposta por Corsaro (2011 p.31) como termo suplente ao de socialização sugere que além da criança abstrair a sociedade e sua cultura também exerce influência sobre ela, acredito que o grupo exemplificou bem essa ideia.

É através da brincadeira que a criança entende o mundo. Para melhor qualidade dessas brincadeiras, os espaços devem ser desafiadores, estimuladores, aconchegantes. É pelo interesse que o ser humano aprende, pela troca, pela participação, com um lugar favorável para essa aprendizagem podemos desenvolver a cognição proporcionando para as crianças o brincar, criar, imaginar, construir suas brincadeiras; "viajar" no mundo das fantasias, do significado.

Permitir que a criança brinque livremente em espaços de qualidade é estimular a produção de conhecimento durante a brincadeira, para que elas superem desde pequenas seus limites e construam suas potencialidades, desenvolvendo diferentes áreas de conhecimento de forma cognitiva e motora e, sobretudo, lúdica.

\section{*Atividade 3 - Direito à atenção individual}

(Construção de desenhos individuais na sala de artes)

A criança, como todo ser humano, é um sujeito social e histórico e faz parte de uma organização familiar que está inserida em uma sociedade, com uma determinada 
cultura, em um determinado momento histórico. Olhando nesta direção, Kramer (2002), explicita isso da seguinte forma:

Dizer que a criança é um ser social significa considerar que ela tem uma história, vive uma geografia, pertence a uma classe social determinada, estabelece relações definidas segundo o seu contexto de origem, apresenta uma linguagem decorrente dessas relações sociais e culturais estabelecidas e ocupa um espaço que não só é geográfico, mas também de valor (p.43).

Hoje já se sabe que a criança deve ser estimulada a adquirir autonomia na solução de problemas e para isso é preciso dar espaço e liberdade para explorar o mundo ao seu redor. A escola é o espaço de socialização que sustenta e desenvolve a formação da identidade da criança, por meio de várias aprendizagens diárias realizadas. Cada criança tem seu ritmo, cada criança aprende uma forma é preciso que a escola respeite e valorize essa diversidade.

Para que a escola possa de fato educar para a liberdade, suas escolhas devem ir ao encontro de atividades pedagógicas que sejam estimulantes, capazes de facilitar e sugerir várias possibilidades de ação, ampliando as vivências das crianças e consequentemente suas experiências. Cada criança precisa de uma atenção individual. Entretanto, mesmo que não seja inviável no cotidiano escolar desenvolver permanentemente esta atenção individualizada, é preciso manter, mesmo que seja de maneira parcial, contatos diretos e individuais com cada criança. É o momento da linguagem pessoal, de orientar seu trabalho, de apoiá-la na aquisição de habilidades ou comportamentos mais específicos de cada criança.

$\mathrm{Na}$ instituição onde aconteceu as observações, a sala de artes é pequena e dividida em dois espaços: um onde fazem as atividades de artes em geral e outro onde brincam no chão com brinquedos diversos. O primeiro espaço dispõe de quatro mesas, duas retangulares e duas quadradas, e cadeiras de madeiras adequadas ao tamanho das crianças.

O grupo chegou à sala, sentou-se a mesa e conversou entre si relatando o que iriam desenhar. Eduardo disse: - "Eu vou desenhar o Pedrinho". Rafael disse: - "Eu vou desenhar o Huck". Eduardo disse: - "Ela me emprestou o verde. Olha é verde!” O Rafael demonstrou gostar muito do verde, a professora explicou que é por causa do Huck e a preferência do Eduardo é por causa do Peter Pan. Eduardo, apesar da preferência, usou outras cores, Rafael só usou o verde. A professora em sua mesa, sequer passeia pela sala observando os desenhos individualmente. 
Maria Luisa estava desenhando e a auxiliar observou que ela usou somente a cor verde e disse: - "Maria Luisa troca de cor. Usa outras cores para ficar bem colorido". Quando a auxiliar percebeu que a Maria Luisa não trocou de cor tirou o lápis dela enquanto ainda desenhava e mandou-a escolher outra cor no pote. Maria Luisa ficou parada sem ação, a auxiliar pegou um lápis e colocou em cima da folha, Maria Luisa empurrou o lápis e depois o pote. Após algum tempo sem desenhar Maria Luisa puxou o pote de volta para perto de si e pegou o verde, ao começar a desenhar foi interrompida pela auxiliar que mais uma vez tirou o lápis da mão dela e deu para outra criança. Maria Luisa desinteressou-se pela proposta. Nesse momento, seria hora da professora dar uma atenção mais individualizada a essa criança. Algo que não aconteceu. Logo depois a professora informou ao grupo que o tempo deles no espaço estava acabando e eles iriam para outro lugar. Assim, sem afeto, sem contexto, jogado mesmo, só pensando no tempo e não na qualidade.

Neste evento observei claramente a invisibilidade da criança mediante a negação da expressão espontânea do seu desenho e seus desejos. A relação adulto e criança ficou na postura do sujeito da apropriação, postura definida por Larrosa (2003) como a relação onde não há espaço nem para o reconhecimento, pois o adulto simplesmente "converte a outra criança em algo à sua medida” (p. 197).

O espaço organizado da melhor maneira oportuniza diferentes vivências para a criança, mas todas elas terão significado se mediadas pelo educador, pois:

"O olhar de um educador atento é sensível a todos os elementos que estão postos em uma sala de aula. $\mathrm{O}$ modo como organizamos materiais, móveis, e a forma como crianças e adultos ocupam esse espaço e como interagem com ele são reveladores de uma concepção pedagógica." (HORN, 2004, p.15)

Levantamos essas questões pois acreditamos, assim como Maria Malta Campos, que na escola de educação infantil, educar significa propiciar situações de cuidados, brincadeiras e aprendizagens orientadas que possam contribuir para o desenvolvimento das capacidades infantis. Cuidar é compreender como ajudar o outro a se desenvolver como ser humano. Precisa considerar as necessidades da criança e estar comprometido com o outro, com sua singularidade, confiando em suas capacidades. A criança na educação infantil precisa também brincar, todas as atividades devem ter o cunho lúdico. Propiciando a brincadeira, cria-se um espaço no qual a criança pode experimentar o mundo e internalizar uma compreensão particular sobre as pessoas, os sentimentos e os diversos conhecimentos. 


\section{*Atividade 4 e 5 - Nossas crianças têm direito a um ambiente aconchegante, seguro e estimulante}

(Brincadeiras com blocos de madeira na sala de jogos)

Cabe aos educadores analisarem e perceberem a importância da organização dos espaços de maneira que atenda às necessidades infantis em prepararem e organizarem a sala para que possibilite maiores aprendizagens e estimule o desenvolvimento da criança, promovendo as mudanças necessárias em sala de aula. Sobre essa organização, Kramer (1993, p.75) nos coloca:

A organização da sala de aula visa, pois, viabilizar que as atividades planejadas por professores e crianças se desenvolvam de maneira flexível, criativa e cooperativa. Essa organização não é estática: novos materiais vão sendo introduzidos ou antigos são arrumados a fim de melhor atender a esse critério.

Porque jogos e brincadeiras são tão importantes no desenvolvimento da curiosidade, imaginação e capacidade de expressão das crianças pequenas? Conforme já frisamos ao longo do percurso no qual se configura este trabalho, entendemos que ao brincar, afeto, motricidade, linguagem, percepção, representação, memória e outras funções cognitivas estão profundamente interligadas.

A brincadeira ajuda no equilíbrio afetivo da criança contribui para o processo de apropriação de signos sociais e linguagens sociais. Por meio da brincadeira, a criança pequena exercita capacidades como: representar o mundo e distinguir pessoas. Ao brincar, a criança passa a compreender as características dos objetos, seu funcionamento, os elementos da natureza e os acontecimentos sociais. Por isso devemos oferecer um espaço lúdico repleto de materiais, jogos, brincadeiras. $\quad \mathrm{O}$ que as crianças usam para brincar, sejam objetos ou personagens, são usados de modo simbólico, Para Vygotsky (1989):

As crianças formam estruturas mentais pelo uso de instrumentos e sinais. A brincadeira, a criação de situações imaginárias surge da tensão do indivíduo e a sociedade. O lúdico liberta a criança das amarras da realidade (p.84).

Na escola de educação infantil analisada a sala é arrumada com jogos diversos e também instrumentos musicais. As estantes são organizadas semanalmente por uma coordenadora para cada grupo. No entanto, acredito que a sala, com suas estantes e espaços, deveria ser organizada pelas próprias crianças, para que criem seus próprios significados. O chão é de taco, as crianças são orientadas a usar um tapete pequeno para apoiar os jogos. No dia que fui observar, a professora ofereceu ao grupo blocos para 
construírem brincadeiras diversas. Algumas crianças entraram em conflito por causa de alguns blocos. Eduardo e Rafael brincavam de construir um castelo quando a Helena pegou algumas peças. Eduardo gritou e Rafael pegou as peças de volta, provocando a reação na Helena de pegar da mão dele. Enquanto Eduardo ficou gritando Rafael e Helena ficaram disputando o brinquedo. Por fim Rafael desistiu e ficou brincando somente com uma peça que já estava com ele, não expressou qualquer reação apenas brincou. Eduardo levantou, foi até a brincadeira que a Helena estava fazendo com a Valentina, e pegou duas peças, elas não falaram nada.

Eduardo voltou para brincar no mesmo grupinho que estava o Rafael. Rafael já estava brincando de outra brincadeira, fez um telefone de construção e ficou envolvido com outras crianças, Eduardo não se importou e começou a construção de um castelo no meio deles. Após algum tempo de brincadeira Eduardo levantou, dirigiu-se até às meninas mencionadas e desmontou tudo que haviam construído. Valentina ficou desapontada e falou para a professora. Ela foi estimulada a resolver o conflito, a professora orientou-a falar a ele que ela não gostou, então ela disse: - "Eduardo eu não gostei. Não pode." e construiu novamente dizendo: - "Eu vou fazer a minha fazenda do meu jeito". Gabriela chegou e falou: -"Vamos montar de novo Valentina"? Segundo Piaget (FLAVELL, 1975, p. 296) o desenvolvimento da moral na faixa etária até cinco anos é determinado pela anomia, onde geralmente a moral não se coloca com as normas de conduta, sendo determinadas pelas necessidades básicas. Quando as regras são obedecidas, são seguidas pelo hábito e não por uma consciência do que se é certo ou errado. Piaget, ainda, argumenta que os valores morais são construídos a partir da interação do sujeito com os diversos ambientes sociais e será durante a convivência diária, principalmente com o adulto, que a criança irá construir seus valores, princípios e normas morais. Assim sendo, podemos concluir que esse processo requer tempo. Neste evento tive a oportunidade de perceber essa característica citada por Piaget na sua teoria, Eduardo e Helena não conseguem resolver o conflito com as normas de conduta combinadas no cotidiano deles. A linguagem, que em outros momentos esteve presente, foi substituída pela expressão corporal, na minha opinião, movimento natural neste momento do desenvolvimento. É através dos jogos, brinquedos e brincadeiras que a criança sente e expressa a curiosidade, importante noção de que viver é brincar. E ao brincar, conhece a si própria e aos outros e realiza a dura tarefa de compreender seus limites e possibilidades e de inserir-se em seu grupo. Aí aprende e 
internaliza normas sociais de comportamentos e os hábitos fixados pela cultura, pela ética e pela moral.

(Brincadeiras com bolas de ar na sala de história)

Todos os professores sabem que os jogos e brincadeiras são sim importantes para a educação, pois todos reconhecem e entendem que a brincadeira é parte integrante do dia a dia das crianças, faz parte de sua formação enquanto ser. O papel do professor durante o processo didático com atividades pedagógicas é provocar participação coletiva e desafiar as crianças a buscarem soluções de modo a promover a criatividade, a fantasia, a ludicidade. Através dos jogos e brincadeiras podemos despertar nelas um senso de companheirismo, cooperação e principalmente autonomia. A criança precisa interagir de forma coletiva, ou seja, precisa apresentar seu ponto de vista, discordar, apresentar suas soluções é necessário também criar ambiente propício e incentivar as crianças a terem pensamento crítico e participativo, fazendo parte das decisões do grupo.

A outra sala analisada nessa escola, é uma sala atapetada (tipo tatame) com prateleiras com livros organizados por temas. Possui um rádio e CDs de músicas. A proposta principal dela é a contação de histórias, no entanto por vezes é usada para outros fins.

Neste dia a professora organizou uma roda, encheu bolas de ar para cada um e colocou o CD de músicas do Sítio do Pica-pau Amarelo para eles brincarem livremente (na verdade o $\mathrm{CD}$ foi um pedido deles). Enquanto ela enchia, uma bola estourou assustando o Eduardo. Todas as crianças do grupo aceitaram as bolas com exceção do Eduardo. Apesar do seu entusiasmo inicial, após o estouro da bola, Eduardo se recusou a ganhar uma bola dizendo: - "Eu não quero Patrícia” ameaçando choro e também se recusou a brincar com as outras crianças que estavam com bolas, ficou encostado na parede tentando afastar-se das bolas que os amigos jogavam para o ar. Por vezes achou algo engraçado e riu. Helena, ao perceber o receio do Eduardo com relação à bola, ficou passando duas bolas na cabeça dele, brincando com ele, deixando-o confortável em relação ao material proposto para a atividade, achando engraçada a reação dele ora parado ora esquivando-se. Quando uma criança jogou a bola para o Eduardo, ele saiu de perto gritando: - "Não". Ao ser indagado pela Eduarda: - "Você não quer uma bola porque está com medo Dudu?" Ele balançou a cabeça de maneira afirmativa então a Eduarda continuou: - "Não precisa ter medo! A bola não vai estourar mais!" 
Após algum tempo Eduardo desencostou da parede e começou a circular pela sala. Gradativamente começou a movimentar o corpo acompanhando o ritmo da música tocada, no entanto manteve a recusa da bola. Rafael que inicialmente aceitou a bola manteve um movimento completamente oposto da maioria que brincou com a bola. Ele ficou fazendo garras e sons como se fosse algum animal tentando estourar as bolas. As crianças demonstraram ao Rafael que não gostaram dos ruídos emitidos por ele falando: - "Para de fazer barulhos Rafael. O meu ouvido está doendo." Também disseram: - "Não pode estourar a minha bola." Por fim ele desistiu e voltou a brincar com a bola apenas de jogá-la para o ar.

Todas as observações provocaram uma autorreflexão da minha prática enquanto profissional da educação infantil e me fizeram pensar principalmente na importância da linguagem no cotidiano das crianças e sobretudo a importância de estar sempre brincando com as crianças, promovendo diferentes brincadeiras, aconchegá-las, confortá-las, dar uma atenção especial para cada uma delas e assim manter um vínculo maior de afeto e confiança.

Apesar de tantas teorias defenderem uma aprendizagem por meio dos jogos, brincadeiras e espontaneidade da criança, as crianças estão longe de usufruir de uma pedagogia fundamentada na ludicidade, criatividade e na expressividade livre dos atos. Para que isso ocorra de maneira proveitosa acredito que precisamos aperfeiçoar e instruir professores, propondo uma pedagogia baseada na interação coletiva, na criatividade, na ludicidade envolvendo todo o contexto escolar. 


\section{Considerações finais}

As últimas reflexões desta monografia, muito mais que conclusões e certezas, trazem questionamentos que venho acumulando ao longo da minha vida profissional e acadêmica, na qual a criança sempre esteve presente em lugar de destaque, ou seja, foi elemento chave da minha ação, a razão das minhas leituras.

Espero que, a priori, da visão de criança que o leitor venha a se identificar, o mesmo possa sempre pensar, lembrar, ouvir, falar, refletir sobre crianças pequenas, como crianças, independente da classe social, raça, credo.

Embora na creche, onde fiz as observações, o carinho e o afeto estivessem presentes todo o tempo, sei que tal fato não corresponde à realidade vivida pela maioria das crianças e, principalmente, por àquelas que estão em instituições.

Chego ao final deste trabalho convicta de que a nossa sociedade ainda necessita refletir muito sobre a criança. Esta criança que ainda não tem os seus direitos de cidadã reconhecidos e necessita de um olhar sensível às suas necessidades e desejos. Para tanto acredito primordialmente na formação de qualidade do professor que merece o incentivo ao aprimoramento, ampliação, significação e ressignificação do próprio olhar para melhor atender as crianças. 


\section{Bibliografia}

ALMEIDA, Paulo Nunes de. Educação lúdica: técnicas e jogos pedagógicos. São Paulo: Edições Loyola, 1987.

BENJAMIN, Walter. Reflexões: a criança, o brinquedo, a educação. São Paulo: Summus, 1984

BRASIL, Ministério da Educação. Secretaria de Educação Básica. Parâmetros Básicos de Infraestrutura para Instituições de Educação Infantil. Brasília: MEC, SEB, 2006.

BRASIL. Diretrizes Curriculares Nacionais da Educação Básica. Brasília: MEC, 2013.

BRASIL/MEC/SEB. Diretrizes curriculares para a educação infantil. Brasília: MEC/SEB, 2009a.

BRASIL. Manual Técnico de Arquitetura e Engenharia. Brasília: MEC/FNDE, 2009b.

BRASIL. Ministério da Educação e do Desporto. Secretaria de Educação Fundamental. Referencial curricular nacional para a educação infantil/Ministério da Educação e do Desporto, Secretaria de Educação Fundamental. - Brasília: MEC/SEF, 1998, volume: 1 ,2 e 3 .

BROUGÉRE, G. Brinquedo e a cultura. 2 ed. São Paulo: Cortez, 1997.

CAMPOS, Maria Malta. Critérios para um atendimento em creches que respeite os direitos fundamentais das crianças / Maria Malta Campos e Fúlvia Rosemberg. - 6.ed. Brasília : MEC, SEB, 2009. 44 p. : il. ISBN 978-85-7783-019-0 1. Creche. 2. Critérios de avaliação. I. Campos, Maria Malta. II. Rosemberg, Fúlvia. III. Brasil. Ministério da Educação. Secretaria de Educação Básica. IV. Título. CDU 373.22 C

CARVALHO, Mara I. Campos; RUBIANO, Marcia R. Bonagamba. Organização do espaço em Instituições Pré-Escolares. In: OLIVEIRA, Zilma de Moraes Ramos (Org.). Educação Infantil: muitos olhares. 2. ed. São Paulo: Cortez, 1995. P.107 - 117.

Flavell, John H. (2001). A psicologia do desenvolvimento de Jean Piaget. São Paulo: Pioneira Thompson Learning.

FREIRE, Paulo. Pedagogia da Autonomia. São Paulo: Paz e Terra, 1996.

GUSMÃO, D. e JOBIM E SOUZA, S. A estética da delicadeza nas roças de Minas: sobre a memória e a fotografia como estratégia de pesquisa - intervenção. In: Psicologia \& Sociedade; 20, Edição Especial: 24-31, 2008.

GANDINI, Lella. Espaços Educacionais e de Envolvimento Pessoal. In: EDWARD, Carolyn; GANDINI, Lella; FORMAN, George. As cem linguagens da criança: A abordagem de Réggio Emília na educação da primeira infância. Porto Alegre: Artes Médicas Sul Ltda., 1999.

HORN, Maria da Graça de Souza. Sabores, cores, sons, aromas. A organização dos espaços na educação infantil. Porto Alegre: Artmed, 2004. 
KRAMER, Sonia (Org.). Com a Pré-Escola nas mãos: Um alternativa curricular para a Educação Infantil. São Paulo: Ática, 1993.

KRAMER, S. Formação de profissionais de educação infantil: questões e tensões. (p.117132) in MACHADO, M.L.A (org.) Encontros e desencontros em Educação Infantil. São Paulo: Cortez, 2002.

LARROSA, Jorge. O enigma da infância ou o que vai do impossível ao verdadeiro. In: LARROSA, J.; LARA, Nuri (Org.) Imagens do outro. Petrópolis: Vozes, 1998.

LOPES, Ana Elisabete. Foto-grafias: as artes plásticas no contexto da escola especial. In: Kramer, S. e Leite, M.I. Infância e Produção Cultural_Campinas: Papirus, 1998.

OLIVEIRA, Vera Barros de. O brincar e a criança do nascimento aos seis anos. Petrópolis: Vozes, 2000.

PASOLINI, Pier Paolo. Gennariello: a linguagem pedagógica das coisas. In:

Os jovens infelizes: antologia de ensaios corsários. São Paulo: Brasiliense, 1990

VYGOTSKY, Lev Semenovich. A Formação Social da Mente . São Paulo : Martins Fontes, 1989. 